\title{
PenERAPAN TRANSHIPMENT: Kaitannya Dengan HaK Bangsa Indonesia Atas Komoditas Perikanan Dan PEMBANGUNAN BERKELANJUTAN
}

\author{
Savitri Nur Setyorini ${ }^{1}$
}

\begin{abstract}
Abstrak
Artikel ini memberikan gambaran mengenai praktik transhipment dan kaitannya dengan hak bangsa Indonesia atas komoditas perikanan dan pembangunan berkelanjutan. Indonesia merupakan produsen ikan terbesar di Asia Tenggara. Namun, terdapat masalah yang mengancam kekayaan laut Indonesia, di antaranya adalah transhipment. Transhipment ini dilakukan dengan memindahkan ikan hasil tangkapan ke kapal lain di tengah laut, untuk kemudian dibawa ke luar negeri. Penelitian ini adalah penelitian kualitatif dengan desain deskriptif analitis. Hasil penelitian menunjukkan bahwa transhipment, yang dewasa ini menjadi suatu kebutuhan dan solusi bisnis, merugikan hak bangsa Indonesia dan tidak sesuai dengan konsep pembangunan berkelanjutan.
\end{abstract}

Kata kunci: ikan, transhipment, hak bangsa Indonesia, pembangunan berkelanjutan

\begin{abstract}
This article provides an overview of transhipment and its relation with the right of Indonesian people and sustainable development. Indonesia is the largest fish producer in Southeast Asia. However, there are several problems threatening the natural wealth of the seas in Indonesia, one of them is transhipment. Transhipment is done by transferring captured fishes from a vessel to another vessel (or vessels) in the middle of the sea, to be brought outside the country. This research is a qualitative research with descriptive analytic design. The result shows that transhipment, which has currently become a necessity and business solution, is causing a loss to the right of Indonesian people and incompatible with the concept of sustainable development.
\end{abstract}

Keywords: fishes, transhipment, right of Indonesian people, sustainable development

\section{Pendahuluan}

Indonesia merupakan negara kepulauan, di mana tiga per empat luasnya merupakan perairan. Dengan perairan yang begitu luas dan dengan kekayaan alamnya, Indonesia memliki potensi yang sangat besar dalam hal industri perikanan. ${ }^{2}$ Berdasarkan data dari Southeast Asian Fisheries Development Center (SEAFDEC), pada tahun 2011 jumlah ikan yang dihasilkan oleh Asia Tenggara adalah sebesar 33,5 juta metric ton (MT), di mana sebanyak 40,7\%-nya dihasilkan oleh Indonesia

1 Staf Pengajar Muda pada Bidang Studi Hukum Administrasi Negara Fakultas Hukum Universitas

2 Perikanan sendiri merupakan semua kegiatan yang berhubungan dengan pengelolaan dan pemanfaatan sumber daya ikan dan lingkungannya mulai dari praproduksi, produksi, pengolahan sampai dengan pemasaran yang dilaksanakan dalam suatu sistem bisnis perikanan. Lihat Indonesia (1), Undang-Undang tentang Perikanan, UU No. 31 Tahun 2004, LN No. 118 Tahun 2004, TLN No. 4433, Ps. 1 angka 1. 
Indonesia dan diikuti oleh Vietnam sebesar 16,2\%, Filipina sebesar 14,8\%, Myanmar sebesar 12,4\%, Thailand sebesar 8,6\%, Malaysia sebesar 5\% dan Kamboja sebesar 1,9\%. ${ }^{3}$ Kemudian, Indonesia juga menjadi produsen ikan terbesar dengan total volume produksi regional sebesar 35,3\% dari perikanan tangkap, dan kemudian diikuti oleh Vietnam sebesar 15,2\%, Filipina $(14.4 \%)$, Myanmar $(14.3 \%)$, Thailand $(10.8 \%)$, and Malaysia $(9.1 \%) .{ }^{4}$ Indonesia juga memimpin dengan jumlah nilai produksi regional sebesar 33,5\% dari jumlah total perikanan tangkap, diikuti oleh Vietnam sebesar 17,9\%, Myanmar (16.9\%), Filipina (14.2\%), Malaysia (10.7\%), dan Thailand $(6.7 \%) .{ }^{5}$ Hal tersebut membuktikan bahwa laut Indonesia sangatlah kaya.

Usaha perikanan di Indonesia sendiri mengalami pertumbuhan yang cukup baik, yakni sekitar 12,9\% pada tahun 2012, dengan hasil yang hampir menyentuh angka enam belas juta ton. Dari hasil tersebut, sebanyak lima juta ton lebih dihasilkan dari perikanan tangkap, terutama perikanan tangkap di laut. ${ }^{6}$ Untuk meningkatkan dan menjaga kekayaan tersebut, maka dalam hal perikanan ini diperlukan kebijakan-kebijakan yang mendukung percepatan pertumbuhan dan pembangunan kelautan dan perikanan, terutama untuk meningkatkan nilai tambah dan daya saing produk kelautan dan perikanan. Untuk itu, maka Pemerintah membuat kebijakan-kebijakan di bidang kelautan dan perikanan. Kebijakan perikanan sendiri dapat dilihat dalam empat fase, yakni: ${ }^{7}$

1) Fase pertama (1968 hingga 1993), fokus sektor perikanan dibagi menjadi dua arah, di mana peningkatan konsumsi domestik menjadi fokus di salah satu pihak, dan mengejar pendapatan melalui ekspor di pihak lain;

2) Fase kedua (1994 hingga 1997), fokus kebijakan perikanan bergeser ke arah pembangunan sumber daya manusia perikanan, seperti peningkatan kesempatan kerja melalui pengembangan kapasitas industri perikanan sejalan dengan peningkatan pasokan dan distribusi produk-produk perikanan;

3) Fase ketiga (1997 hingga 1998), kebijakan-kebijakan perikanan merupakan bagian dan cerminan dari upaya Pemerintah dalam menanggulangi krisis moneter dan ekonomi yang tengah melanda, antara lain dengan berusaha meningkatkan ekspor komoditas perikanan yang memang merupakan salah satu sektor yang paling minimal terkena dampak krisis; dan

4) Fase keempat (1998 hingga sekarang), ditandai dengan berbagai formula desentralisasi pengelolaan perikanan. Dalam fase ini, kebijakan perikanan memiliki beberapa arah, yaitu:

a) Peningkatan manajemen partisipatif, termasuk meningkatkan peranan dan partisipasi pemerintah daerah, masyarakat adat dan perempuan dalam pengelolaan ikan;

b) Promosi investasi perikanan dan perbaikan tatanan kelembagaan ke arah iklim yang lebih kondusif bagi peningkatan investasi dan mempertinggi nilai tambah komoditas perikanan; dan

c) Perbaikan sarana dan prasarana perikanan untuk memfasilitasi kegiatan perdagangan komoditas perikanan yang lebih bergairah.

Kemudian, pada tahun 2012 Pemerintah kembali merumuskan kebijakan dalam hal kelautan dan perikanan sebagaimana dicantumkan pada Peraturan Menteri Kelautan dan

\footnotetext{
3 Southeast Asian Fisheries Development Center, Fishery Statistikal Bulletin of Southeast Asia 2011 (Bangkok: Southeast Asian Fisheries Development Center, 2013), hal. 3.

${ }^{4}$ Ibid., hal. 5.

${ }^{5}$ Ibid.

6 Kementerian Kelautan dan Perikanan, "Volume Produksi Perikanan," http://statistik.kkp.go.id/index.php/dashboard/c/3/?iframe=true\&width=100\%\&height $=95 \%$, diakses pada 27 Agustus 2014.

7 Bono Budi Priambodo, Ikan untuk Nelayan (Depok: Badan Penerbit Fakultas Hukum Universitas Indonesia, 2013), hal. 39-40.
} 
Perikanan Nomor PER.15/MEN/2012 tentang Rencana Strategis Kementerian Kelautan dan Perikanan Tahun 2010-2014. Adapun kebijakan-kebijakan tersebut, di antaranya:

a. Mengembangkan industrialisasi kelautan dan perikanan, dengan tujuan untuk meningkatkan kontribusi sektor kelautan dan perikanan terhadap pertumbuhan ekonomi dan meningkatkan kesejahteraan rakyat;

b. Peningkatan produktivitas, efisiensi, dan nilai tambah produk;

c. Pengembangan dan pengawasan sistem jaminan mutu dan traceability (penelusuran) produk hasil perikanan dan jaminan ketersediaan bahan baku industri;

d. Konservasi dan rehabilitasi sumberdaya kelautan dan perikanan serta pengelolaan pulaupulau kecil dan upaya adaptasi dan mitigasi bencana dan perubahan iklim untuk wilayah pesisir dan pulau-pulau kecil;

e. Pengawasan pemanfaatan sumber daya kelautan dan perikanan;

f. Pengembangan sumberdaya manusia dan IPTEK kelautan dan perikanan;

g. Peningkatan kesejahteraan nelayan dan masyarakat perikanan dengan fokus pada Program Peningkatan Kehidupan Nelayan; dan

h. Percepatan dan perluasan pembangunan ekonomi sektor kelautan dan perikanan, terutama di Koridor Ekonomi Sulawesi, Bali-Nusa Tenggara, dan Maluku-Papua.

Namun ternyata, dari kebijakan-kebijakan di bidang kelautan dan perikanan tersebut belum dapat mengakomodasi permasalahan yang mengancam kekayaan laut Indonesia, di antaranya adalah Illegal, Unreported and Unregulated Fishing (IUU Fishing), yang sekiranya dapat merugikan negara hingga dua juta dollar dalam satu tahun. ${ }^{8}$ Secara sederhana, illegal fishing berarti penangkapan ikan secara ilegal atau pencurian ikan. Sementara itu, unreported fishing diartikan sebagai tidak adanya pelaporan atas ikan yang ditangkap, dan unregulated fishing adalah kegiatan penangkapan ikan yang tidak diatur oleh negara yang bersangkutan. ${ }^{9}$

Adapun salah satu masalah yang timbul dari IUU Fishing tersebut adalah transhipment atau alih muat, yakni pengalihan muatan dari satu kapal ke kapal lain di tengah laut. Menurut data Koalisi Rakyat untuk Keadilan Perikanan (KIARA), dari tahun 2001 hingga 2013, terdapat 6.215 kasus pencurian ikan, dan enam puluh persen lebih atau 3.782 kasus terjadi hingga November 2012.10 Kegiatan transhipment ini, selain mengancam kekayaan laut Indonesia, tentunya akan sangat merugikan karena komoditas perikanan yang seharusnya dinikmati oleh bangsa Indonesia dialihmuatkan kepada kapal lain. Selain itu, kegiatan ini juga akan mempengaruhi elemen-eleman pembangunan berkelanjutan. Oleh karena itu, Penulis akan membahas lebih lanjut mengenai kegiatan transhipment ini beserta kaitannya dengan hak bangsa Indonesia atas komoditas perikanan dan pembangunan berkelanjutan.

${ }^{8}$ Hal ini dikemukakan oleh B. Fegan dalam "Plundering the Sea: Regulating Trawling Companies is Difficult When the Navy is in Business with Them," sebagaimana dikutip dalam Gerd Winter (Ed), Toward Sustainable Fisheries Law. A Comparative Analysis (Switzerland: IUCN, 2009), hal. 42.

9 Hal ini disampaikan oleh Dikdik Mohamad Sodik dalam "IUU Fishing and Indonesia's Legal Framework for Vessel Licensing," sebagaimana dikutip dalam Amelya Gustina, "Analisis Transhipment Pasal 69 ayat (3) Peraturan Menteri Kelautan Perikanan No. 30 Tahun 2012 tentang Usaha Perikanan Tangkap," Jurnal Dinamika Hukum, Volume 14, Nomor 2 (Mei 2014), hal. 341.

10 Sabar Subekti, "Pencurian Ikan Masih Marak di Lautan Indonesia," http://www.satuharapan.com/read-detail/read/pencurian-ikan-masih-marak-di-lautan-indonesia diakses pada 3 Oktober 2014. 


\section{Kaitan Transhipment, Hak Bangsa Indonesia atas Komoditas Ikan dan Pembangunan Berkelanjutan}

\subsection{Transhipment}

Transhipment atau alih muatan merupakan salah satu bentuk dari IUU Fishing11, dan diatur dalam Peraturan Menteri Kelautan dan Perikanan Nomor 30/PERMENKP/2012, mulai dari Pasal 69 hingga Pasal 71. Adapun transhipment ini didefinisikan sebagai pemindahan ikan hasil tangkapan dari kapal penangkap ikan ke kapal pengangkut ikan atau pemindahan hasil tangkapan dari kapal penangkap ikan ke kepal penangkap ikan. ${ }^{12}$

Kemudian, dalam Pasal 69 ayat (2) peraturan ini, ditentukan bahwa kebijakan transhipment ini dapat digunakan oleh setiap kapal penangkap ikan dan/atau kapal pengangkut ikan, dengan ketentuan: 1) mempunyai pelabuhan pangkalan yang sama; 2) pelaksanaan transhipment diawasi oleh pemantau kapal penangkap ikan dan kapal pengangkut ikan (observer); 3) transmitter vessel monitoring system (VMS) dalam kondisi aktif dan dapat dipantau secara online; 4) melaporkan kepada kepala pelabuhan pangkalan sebagaimana tercantum dalam Surat Izin Penangkapan Ikan (SIPI) atau Surat Izin Kapal Pengangkut Ikan (SIKPI); 5) melaporkan kepada pengawas perikanan di pelabuhan pangkalan sebagaimana tercantum dalam SIPI atau SIKPI; dan 6) mengisi pernyataan pemindahan ikan hasil tangkapan yang ditandatangani oleh masing-masing nakhoda kapal dan disampaikan kepada kepala pelabuhan pangkalan.

Dalam pelaksanaan transhipment ini, ikan wajib didaratkan di pelabuhan pangkalan sesuai SIPI atau SIKPI dan tidak dibawa keluar negeri, kecuali bagi kapal penangkap ikan yang menggunakan alat penangkapan ikan purse seine berukuran diatas seribu gross ton (GT) yang dioperasikan secara tunggal. ${ }^{13}$ Selain itu, ditentukan pula bahwa setiap kapal pengangkut ikan yang menggunakan pola kemitraan dapat melakukan alih muatan dengan ketentuan:

a) Kapal penangkap ikan berukuran sampai dengan $10 \mathrm{GT}$;

b) Kegiatan penangkapan ikan dan pengangkutan ikan dilakukan oleh kapal yang memiliki izin atau Bukti Pencatatan Kapal dan merupakan mitranya;

c) Ikan yang dipindahkan wajib didaratkan di pelabuhan pangkalan kapal pengangkut ikan yang menerima pemindahan ikan hasil tangkapan; dan

d) Mengisi pernyataan pemindahan ikan hasil tangkapan dan ditandatangani oleh masing-masing nahkoda kapal dan disampaikan kepada kepala pelabuhan pangkalan. ${ }^{14}$

Pada tahun 2013, Peraturan Menteri Nomor 30/PERMEN-KP/2012 ini diubah dengan Peraturan Menteri Nomor 26/PERMEN-KP/2013, dan ketentuan Pasal 69 hingga Pasal 71 dihapuskan. Namun ternyata, revisi tersebut masih membuka celah adanya alih

${ }^{11}$ Lihat Bab III Lampiran I Keputusan Menteri Kelautan dan Perikanan Nomor 50 Tahun 2012 tentang Rencana Aksi Nasional Pencegahan dan Penanggulangan Illegal, Unreported, and Unregulated Fishing Tahun 20122016.

12 Kementerian Kelautan dan Perikanan, Peraturan Menteri Kelautan dan Perikanan tentang Usaha Perikanan Tangkap di Wilayah Pengelolaan Perikanan Negara Republik Indonesia, Permen KKP Nomor 30/PERMEN-KP/2012, Pasal. 1 angka 34.

${ }^{13}$ Ibid., Pasal. 69 ayat (3).

${ }^{14}$ Ibid., Pasal. 70 ayat (1). 
muatan di laut melalui Pasal 37 ayat (7) dan (8) serta Pasal 37A, 37B dan 37C, yang mengatur persyaratan usaha pengangkutan ikan dengan pola kemitraan. ${ }^{15}$

Indonesia sendiri sebenarnya telah memperkenalkan suatu sistem pemantauan kapal melalui VMS, untuk menjamin ketaatan kapal ikan terhadap ketentuan yang berlaku terhadapnya, di mana sistem ini digunakan untuk memantau posisi kapal yang telah diberi izin untuk menangkap ikan di yurisdiksi nasional atau wilayah tertentu. ${ }^{16}$ Namun sayangnya, masih banyak yang mematikan sistem ini ketika mereka sedang menangkap ikan. ${ }^{17}$ Dengan dimatikannya sistem tersebut, maka aktivitas yang dilakukan, termasuk transhipment, tidak akan terpantau.

\subsection{Transhipment dan Hak Bangsa Indonesia atas Komoditas Perikanan}

Adanya kebijakan transhipment ini untuk selanjutnya menimbulkan beberapa pembahasan. Pembahasan pertama adalah mengenai kaitan antara transhipment dan hak bangsa Indonesia atas komoditas perikanan. Seperti telah disebutkan sebelumnya, perairan Indonesia, terutama laut sangatlah kaya. Kekayaan Indonesia tersebut, dalam hal ini adalah kekayaan laut Indonesia, merupakan milik dan hak dari bangsa Indonesia. Hal ini dapat dilihat dari Pasal 33 ayat (3) Undang-Undang Dasar Negara Republik Indonesia Tahun 1945, di mana disebutkan bahwa, "bumi, air dan kekayaan alam yang terkandung di dalamnya dikuasai oleh negara dan dipergunakan untuk sebesar-besar kemakmuran rakyat." Selanjutnya, pada Pasal 1 ayat (1) Undang-Undang Nomor 5 Tahun 1960 tentang Peraturan Dasar Pokok-Pokok Agraria (UUPA), yang menyebutkan bahwa, "seluruh wilayah Indonesia adalah kesatuan tanah-air dari satu seluruh rakyat Indonesia, yang bersatu sebagai bangsa Indonesia." 18 berbunyi:

Kemudian, hal tersebut dijabarkan pula dalam Pasal 1 ayat (2) UUPA, yang

Seluruh bumi, air dan ruang angkasa, termasuk kekayaan alam yang terkandung di dalamnya dalam wilayah Republik Indonesia sebagai karunia Tuhan Yang Maha Esa adalah bumi, air dan ruang angkasa bangsa Indonesia dan merupakan kekayaan nasional. ${ }^{19}$

Kemudian, mengenai Pasal 1 ayat (1) dan ayat (2) di atas dalam Penjelasan Umum UUPA, disebutkan bahwa:

Bumi, air dan ruang angkasa dalam wilayah Republik Indonesia yang kemerdekaannya diperjuangkan oleh bangsa sebagai keseluruhan, menjadi hak pula dari bangsa Indonesia, jadi tidak semata-mata menjadi hak rakyat

15 Dalam Pasal 37 ayat (7) dan (8) disebutkan bahwa pendaratan ikan hasil tangkapan dari kapal penangkap ikan dapat dilakukan langsung pada pelabuhan pangkalan atau melalui alih muatan di laut, dengan ketentuan: 1) mempunyai pelabuhan pangkalan yang sama; 2) pelaksanaan alih muatan diawasi oleh pemantau kapal penangkap ikan dan kapal pengangkut ikan (observer); transmitter VMS dalam kondisi aktif dan dapat dipantau secara online; 3) melaporkan kepada kepala pelabuhan pangkalan sebagaimana tercantum dalam SIPI atau SIKPI; 4) melaporkan kepada pengawas perikanan di pelabuhan pangkalan sebagaimana tercantum dalam SIPI atau SIKPI; dan 5) mengisi pernyataan pemindahan ikan hasil tangkapan yang ditandatangani oleh masingmasing nakhoda kapal dan disampaikan kepada kepala pelabuhan pangkalan. Sedangkan, Pasal 37A memiliki ketentuan yang sama dengan Pasal 70 ayat (1) Peraturan Menteri Kelautan dan Perikanan Nomor 30/PERMEN$\mathrm{KP} / 2012$, hanya perubahan kata "transhipment" menjadi "alih muatan".

16 Melda Kamil Ariadno, Hukum Internasional Hukum yang Hidup (Jakarta: Diadit Media, 2007), hal. 129.

${ }^{17}$ Hal ini dikemukakan oleh M.V. Erdman dalam “Leave Indonesia's Fisheries to Indonesians! Corrupt Foreign Fishing Fleets are Depriving Locals of Food," sebagaimana dikutip dalam Gerd, op. cit., hal. 44.

18 Indonesia (2), Undang-Undang tentang Peraturan Dasar Pokok-Pokok Agraria, UU No. 5 Tahun 1960.,LN No. 104 Tahun 1960, TLN Nomor 2043, Pasal. 1 ayat (1).

19 Ibid., Pasal. 1 ayat (2) 
daerah dan pulau-pulau, tidaklah semata-mata menjadi hak rakyat asli dari daerah atau pulau yang bersangkutan. Dengan pengertian demikian maka hubungan bangsa Indonesia dengan bumi, air dan ruang angkasa Indonesia merupakan semacam hubungan hak ulayat, yang diangkat pada tingkatan yang paling atas, yaitu tingkatan yang mengenai seluruh wilayah negara.

Berdasarkan hal tersebut di atas, maka dapat dilihat bahwa kekayaan alam Indonesia, yang terdiri dari bumi, air ${ }^{20}$ dan ruang angkasa merupakan suatu hak bersama dari seluruh rakyat Indonesia, atau biasa disebut dengan hak bangsa Indonesia. Konstruksi hukum hak bangsa Indonesia ini kemudian berimplikasi pada kepemilikan bersama segala kekayaan alam yang berada di dalam wilayah kedaulatan negara Republik Indonesia oleh seluruh bangsa Indonesia. ${ }^{21}$ Oleh karena itu, terkait dengan sumberdaya ikan, baik ikan yang selalu berdiam dalam perairan Indonesia atau sering melintas dan berpindah-pindah dalam wilayah Zona Ekonomi Eksklusif Indonesia, adalah milik bersama warga negara Indonesia. ${ }^{22}$ Oleh karena itu, komoditas perikanan pun merupakan hak dari bangsa Indonesia, yang harus dapat dirasakan dan dinikmati bersama oleh seluruh rakyat Indonesia.

Berkaitan dengan hak bangsa Indonesia tersebut, maka kegiatan transhipment sangat merugikan bangsa Indonesia. Dengan adanya kegiatan transhipment tersebut, maka ikan yang seharusnya menjadi milik bangsa Indonesia menjadi hilang karena kebijakan transhipment ini memperburuk kegiatan illegal fishing, ${ }^{23}$ di mana ikan-ikan hasil tangkapan di wilayah perairan Indonesia dapat langsung dipindahkan di tengah laut ke kapal lain untuk kemudian dibawa ke luar negeri. Berdasarkan data Koalisi Rakyat untuk Keadilan Perikanan (KIARA), kasus illegal fishing meningkat drastis, di mana sepanjang tahun 2001 hingga tahun 2013, terdapat 6.215 kasus illegal fishing dan 60\% nya terjadi pada tahun $2012 .{ }^{24}$

Kemudian, kebijakan transhipment ini mengatur bahwa kapal penangkap ikan berukuran lebih dari 1.000 GT justru tidak diwajibkan didaratkan di pelabuhan pangkalan sesuai SIPI atau SIKPI. Padahal, pelaku pencurian ikan merupakan jenis kapal besar, seperti 1.000 GT. ${ }^{25}$ Selain itu, berdasarkan data Kesatuan Nelayan Tradisional

${ }^{20}$ Menurut Boedi Harsono, ketentuan yang ada dalam UUPA mencakup pula air dalam arti laut, selain air yang ada di daratan ataupun air tanah. Lihat Boedi Harsono, Hukum Agraria Indonesia Sejarah Pembentukan Undang-Undang Pokok Agraria, Isi dan Pelaksanaannya (Jakarta: Universitas Trisakti, 2013), hal. 6-7.

${ }^{21}$ Priambodo, op. cit., hal. 73.

22 Ibid.

${ }^{23}$ Illegal fishing dapat diartikan sebagai kegiatan penangkapan ikan yang dilakukan oleh orang atau kapal asing pada suatu yurisdiksi suatu negara tanpa izin dari negara tersebut atau bertentangan dengan peraturan perundang-undangan yang berlaku dan bertentangan dengan peraturan nasional dan/atau kewajiban internasional dan dilakukan oleh kapal yang mengibarkan bendera suatu negara yang menjadi anggota organisasi pengelolaan perikanan regional, tetapi beroperasi tidak sesuai dengan ketentuan pelestarian dan pengelolaan yang diterapkan oleh organisasi tersebut atau oleh ketentuan hukum internasional. Adapun kegiatan kegiatan illegal fishing di Indonesia meliputi penangkapan ikan tanpa izin, penangkapan ikan dengan mengunakan izin palsu, penangkapan Ikan dengan menggunakan alat tangkap terlarang, dan penangkapan Ikan dengan jenis (spesies) yang tidak sesuai dengan izin. Lihat Simela Victor Muhamad, "Kejahatan Transnasional Illegal fishing di Perairan Indonesia dan Upaya Penanganannya Secara Regional di Asia Tenggara," dalam Laporan Hasil Penelitian Pusat Pengkajian, Pengolahan Data, dan Informasi (P3DI) Sekretariat Jenderal Dewan Perwakilan Rakyat Republik Indonesia tentang Masalah-Masalah Hubungan Internasional pada Tahun 2011, hal. 65. Dalam Keputusan Menteri Kelautan dan Perikanan Nomor 50 Tahun 2012, definisi dari illegal fishing ini ditambahkan satu poin, yakni kegiatan perikanan yang bertentangan dengan hukum nasional atau kewajiban internasional, termasuk juga kewajiban negara-negara anggota organisasi pengelolaan perikanan regional terhadap organisasi tersebut.

24 Sulung Prasetyo, "Pencurian Ikan Meningkat Drastis," http://www.kiara.or.id/pencurian-ikanmeningkat-drastis/, diunduh pada 22 Agustus 2014.

${ }^{25} \mathrm{Ibid}$. 
Indonesia (KNTI), Indonesia tidak memiliki kapal berbobot 1.000 GT. ${ }^{26}$ Adapun kegiatan transhipment ini umumnya terjadi di daerah perbatasan yang memiliki banyak ikan, seperti Laut Aru, Laut Arafuru, Perairan Natuna dan laut-laut yang berada di daerah Nusa Tenggara. ${ }^{27}$

Selain illegal fishing, kebijakan transhipment ini juga berkaitan unreported fishing, atau penangkapan ikan yang tidak dilaporkan. Unreported fishing merupakan kegiatan penangkapan ikan yang:28

a. tidak melapor atau melaporkan hasil tangkapan secara tidak benar kepada instasi yang berwenang dan menyalahi peraturan perundang-undangan nasional; dan

b. dilakukan di area yang menjadi kompetensi Regional Fisheries Management Organizations (RMFOs), namun tidak pernah dilaporkan atau dilaporkan secara tidak benar.

Kegiatan unreported fishing di Indonesia di antaranya adalah pemalsuan data tangkapan atau tidak melaporkan hasil tangkapan yang sesungguhnya dan membawa hasil tangkapan langsung ke negara lain. ${ }^{29}$ Berdasarkan hal tersebut, dapat dilihat bahwa kebijakan transhipment ini berimbas pada ketidakakuratan pencatatan jumlah produksi ikan di Indonesia, karena jumlah ikan yang ditangkap akan berbeda dengan jumlah ikan yang didaratkan dan dicatatkan di pelabuhan perikanan. Hal ini tentunya menyebabkan kerugian pada negara, dimana pemasukan negara yang seharusnya didapat dari komoditas perikanan menjadi berkurang karena jumlah yang dilaporkan berbeda dengan jumlah yang ditangkap.

Ketiga, kebijakan transhipment ini tidak sesuai dengan Undang-Undang Nomor 45 Tahun 2009 yang merupakan perubahan atas Undang-Undang Nomor 31 Tahun 2004. Dalam Pasal 25B ayat (2) disebutkan bahwa disebutkan bahwa pengeluaran hasil produksi usaha perikanan ke luar negeri dilakukan apabila produksi dan pasokan di dalam negeri telah mencukupi kebutuhan konsumsi nasional. Bunyi pasal tersebut merepresentasikan hak bangsa Indonesia atas pemenuhan kebutuhan protein hewani, yakni ikan. Namun, dengan adanya kebijakan transhipment yang memperbolehkan adanya alih muatan ikan di atas laut ke kapal lain dan kemudian dibawa ke luar negeri tidak memenuhi ketentuan Pasal 25B ayat (2) tersebut, karena ikan telah lebih dulu dibawa ke luar negeri sebelum digunakan untuk memenuhi kebutuhan konsumsi ikan di dalam negeri, yang yang artinya hak bangsa Indonesia atas pemenuhan kebutuhan protein tidak dapat terpenuhi.

Berdasarkan hal-hal di atas, dapat dilihat bahwa praktik transhipment ini tentunya merugikan Indonesia, dimana ikan yang seharusnya menjadi hak bangsa Indonesia, justru tidak dapat dinikmati oleh bangsa Indonesia, baik untuk dikonsumsi ataupun sebagai pemasukan negara, ${ }^{30}$ karena telah dialihmuatkan dan dibawa ke luar negeri.

26 Administrator, "KNTI Tolak Izin Transhipment Kapal 1000 GT," http://www.republika.co.id/berita/ekonomi/bisnis/13/03/13/mjla4u-knti-tolak-izin-transhipment-kapal-1000-gt, diunduh pada 22 Agustus 2014.

27 Mukhtar, "Kerugian Negara di Perairan Laut Aru dan Laut Arafura," http:// www.kkp.go.id/index.php/arsip/c/10347/Kerugian-Negara-di-Perairan-Laut-Aru-dan-LautArafura/?category_id=91, diunduh pada 22 Agustus 2014.

${ }^{28}$ Muhamad, loc. cit.

${ }^{29} \mathrm{Ibid}$.

${ }^{30}$ Menurut Wakil Ketua Komisi IV Dewan Perwakilan Rakyat Indonesia, Indonesia telah kehilangan tiga puluh triliun dari tindak illegal fishing, Bila setiap pencurian itu dihargai sebesar sepuluh ribu rupiah per kilogram, maka volume ikan yang dicuri setara dengan tiga juta ton setiap tahun, dimana angka kehilangan ikan itu sebenarnya mencukupi jika digunakan untuk memenuhi kebutuhan industri perikanan. Lihat Ranap Simanjuntak, "Cold storage: Hangatnya Proyek Pendingin," http://m.sindoweekly-magz.com/artikel/11/i/17-23-mei2012/business/22/hangatnya-proyek-pendingin, diakses pada 3 Oktober 2014. 


\subsection{Transhipment dan Konsep Pembangunan Berkelanjutan}

Pembahasan kedua mengenai praktik transhipment atau alih muatan komoditas perikanan ini adalah kaitannya dengan konsep pembangunan berkelanjutan atau sustainable development. Konsep sustainable development atau pembangunan berkelanjutan merupakan hasil dari proses perdebatan panjang antara kebutuhan akan pembangunan dan kesadaran akan pentingnya perlindungan lingkungan hidup yang dimulai sekitar tahun 1960an. ${ }^{31}$

Pada tahun 1983, Majelis Umum PBB membuat sebuah lembaga yang bertugas mengkaji ulang beberapa masalah penting yang terkait dengan pembangunan dan lingkungan hidup, serta merumuskan langkah yang inovatif, kongkrit dan realistis yang untuk mengatasi permasalahan-permasalahan tersebut. Lembaga ini bernama World Commission on Environment and Development (WCED) atau sering disebut sebagai Brundtland Commission. ${ }^{32}$

Pada tahun 1987, WECD mengeluarkan sebuah laporan berjudul "Our Common Future" dan mempopulerkan istilah sustainable development atau pembangunan berkelanjutan, yang mempengaruhi pembuatan kebijakan internasional. WECD kemudian mendefinisikan pembangunan berkelanjutan sebagai:

"Development that meets the needs of the present without compromising the ability of future generations to meet their own needs. It contains within two key concepts:

1. The concept of 'needs', in particular the essential needs of the world's poor, to which overriding priority should be given; and

2. The idea of limitations imposed by the state of technology and sosial organization on the environment's ability to meet present and future." 33

Berdasarkan hal tersebut, dapat dilihat elemen-elemen pembangunan berkelanjutan berdasarkan definisi dari WECD, di antaranya prinsip integrasi (integration principle), prinsip pemanfaatan berkelanjutan (sustainable use), prinsip keadilan intra generasi (intragenerational equity), dan prinsip keadilan antargenerasi (intergenerational equity).

Hal serupa dikemukakan oleh Philippe Sands, yang membagi pembangunan berkelanjutan ke dalam beberapa prinsip, yakni: ${ }^{34}$

a. keadilan antargenerasi (intergenerational equity), yang dapat dilihat dari kebutuhan untuk melindungi SDA bagi keuntungan generasi yang akan datang;

b. pemanfaatan secara bekelanjutan (the principle of sustainable use), yang direfleksikan dalam eksploitasi SDA secara berkelanjutan (sustainable), hati-hati (prudent), rasional (rational), bijaksana (wise), dan layak (appropriate);

31 Kepedulian dunia akan lingkungan dimulai pada tahun 1962, yakni dengan diterbitkannya sebuah buku yang ditulis oleh Rachel Carson tentang bahaya dari penggunaan pestisida, "the Silent Spring" yang diterbitkan di New York oleh Marnier Book Houghton Mifflin Company. Selain itu, hal ini juga ditandai dengan kelahiran beberapa organisasi lingkungan, seperti Sierra Club dan National Audubon Society, yang kemudian menjadi pertanda akan lahirnya ratusan ribu organisasi lingkungan di seluruh dunia. Lihat T. Brenton, The Greening of Machiavelli: the Evolution of International Environmental Politics (London: Earthscan, 1994), hal. 18-19.

32 Andri G. Wibisana, "Pembangunan Berkelanjutan: Status Hukum dan Pemaknaannya," Jurnal Hukum dan Pembangunan, Volume 43, Nomor 1 (Januari 2013), hal. 57.

33 Sharon Beder, Environmental Principles and Policies: An Interdiciplinary Introduction (Earthscan, 2006), hal. 18. Lihat juga Wibisana, Ibid., hal. 86-87.

34 Philippe Sands, Principles of International Environmental Law: Vol. 1, Frameworks, Standards, and Implementation (Manchester University Press, 1995), hal. 199. Lihat juga Wibisana, ibid. 
c. keadilan intra generasi, yang ditunjukkan melalui pemanfaatan SDA secara berkeadilan (equitable use of natural resources), di mana pemanfaatan SDA oleh satu negara tetap harus memperhatikan kebutuhan dari negara lain; dan

d. prinsip integrasi (integration principle), yang meminta adanya jaminan bahwa pertimbangan lingkungan akan diintegrasikan ke dalam rencana, kebijakan, serta program terkait ekonomi dan pembangunan, serta bahwa pemenuhan kebutuhan pembangunan harus memperhatikan tujuan perlindungan lingkungan.

Elemen integrasi dapat disimpulkan dari adanya pengakuan mengenai kebutuhan akan pembangunan pada satu sisi, tetapi pada sisi lain diakui pula bahwa pemenuhan kebutuhan akan pembangunan ini tidak boleh menganggu kemampuan generasi yang akan datang untuk memenuhi kebutuhan mereka. Elemen pemanfaatan yang berkelanjutan dapat dilihat dari adanya pengakuan terhadap dampak teknologi dan organisasi sosial terhadap kemampuan lingkungan untuk memenuhi kebutuhan generasi sekarang dan akan datang, serta adanya pengakuan bahwa pembangunan yang dilakukan tetap memperhatikan kepentingan generasi yang akan datang. Elemen keadilan intra generasi dapat dilihat dari pendefinisian kata kebutuhan (needs) yang memberikan prioritas pada pemenuhan kebutuhan masyarakat yang miskin. Sedangkan elemen keadilan antar generasi dapat disimpulkan dari adanya pengakuan mengenai keseimbangan antara pemenuhan kebutuhan generasi sekarang dengan kebutuhan generasi yang akan datang. ${ }^{35}$

Dari penjelasan keempat elemen mengenai pembangunan berkelanjutan yang dikemukakan oleh WECD, dapat dilihat benang merah di antaranya, yakni mengenai pembangunan lingkungan dan kebutuhan bagi generasi sekarang (intra generasi) dan generasi yang akan datang (antargenerasi). Jika benang merah dari elemen-elemen tersebut dihubungkan dengan transhipment, maka dapat dilihat bahwa kegiatan transhipment ini dapat mengakibatkan kerugian bagi generasi yang sekarang maupun generasi yang akan datang. Hal ini dikarenakan, ikan yang seharusnya dapat dimanfaatkan oleh generasi sekarang, maupun generasi yang akan datang, justru tidak dapat dinikmati atau tidak dapat dinikmati secara maksimal karena adanya alih muatan dan hasil tangkapan ikan langsung dibawa ke luar negeri. Selain itu, pemasukan yang didapat dari komoditas perikanan juga tidak akan maksimal karena dengan adanya transhipment ini akan terjadi bias dalam pencatatan perikanan. Hal ini tentunya akan merugikan generasi sekarang yang akan datang karena, sekali lagi, transhipment ini menjadi faktor yang memperburuk illegal dan unreported fishing.

Namun, perihal elemen pembangunan berkelanjutan bagi generasi sekarang dan generasi yang akan datang tidak boleh hanya dilihat dari satu sisi, yakni sisi ekonomi saja. Tetapi, harus pula dilihat berdasarkan sisi lain, yakni sosial-budaya dan ekologi. ${ }^{36}$ Dari sisi sosial-budaya, haruslah dilihat mengenai hal-hal seperti perilaku konsumsi ikan masyarakat Indonesia ataupun pasar untuk komoditas ikan. Berdasarkan data dari Kementerian Kelautan dan Perikanan, pada tahun 2012 jumlah konsumsi ikan Indonesia adalah sebesar 33,89 kg/kapita/tahun. ${ }^{37}$ Jumlah konsumsi ikan ini hanya seperlima dari jumlah konsumsi ikan Jepang yang mencapai 150 kg/kapita/tahun. ${ }^{38}$ Kemudian, untuk

35 Wibisana, op. cit., hal. 87.

36 Illegal dan unreported fishing berasal dari sisi ekonomi. Wawancara lisan dengan Bono Budi Priambodo, Pengajar Matakuliah Hukum Lingkungan Fakultas Hukum Universitas Indonesia dan Penulis Buku Ikan untuk Nelayan, Depok, 22 Agustus 2014.

37 Kementerian Kelautan dan Perikanan, "Angka Konsumsi Ikan," http:// statistik.kkp.go.id/index.php/dashboard/c/4/?iframe=true\&width=100\%\&height $=95 \%$, diakses pada 27 Agustus 2014.

38 Ramdhania El Hida, "Konsumsi Ikan Orang Indonesia Hanya Seperlima Jepang," http:/ finance.detik.com/read/2011/08/24/165017/1710441/4/konsumsi-ikan-orang-indonesia-hanyaseperlima-jepang, diakses pada 27 Agustus 2014. 
pasar bagi komoditas ikan ini sendiri belum dapat diakomodasi oleh Indonesia, dan umumnya masih berada di bagian utara Indonesia. ${ }^{39}$ Selanjutnya, dari sisi ekologi, haruslah memperhatikan pengukuran atau pencatatan dari ikan yang ditangkap, selain dengan cara didaratkan terlebih dahulu. Hal ini sejatinya dapat dilaksanakan dengan melakukan kerjasama statistik dengan negara-negara lain, baik secara bilateral maupun multilateral. Dengan begitu, maka diharapkan pembangunan berkelanjutan dalam hal perikanan dapat menghasilkan kemanfaatan bagi generasi sekarang maupun generasi yang akan datang, baik secara ekonomi, sosial-budaya, maupun secara ekologi.

\subsection{Keniscayaan Transhipment}

Seperti telah dijabarkan sebelumnya, transhipment atau alih muatan atas komoditas perikanan dari satu kapal ke kapal lain di atas laut dan dibawa ke luar negeri tidak sejalan dengan hak bangsa Indonesia dan juga pembangunan berkelanjutan dan tentunya merugikan Indonesia. Namun, pada kenyataannya, praktik transhipment tetap berjalan dan bahkan masih terbuka celah untuk melakukan hal tersebut dalam peraturan yang berlaku.

Menurut Bono Budi Priambodo, praktik transhipment dapat dikatakan sebagai suatu kebutuhan. ${ }^{40}$ Hal ini berkaitan dengan komoditas perikanan yang memiliki perbedaan dengan komoditas lain. Jika komoditas lain akan memiliki nilai tambah lebih tinggi jika diolah terlebih dahulu, maka komoditas perikanan justru akan memiliki nilai tambah yang lebih tinggi jika tidak diolah. Komoditas perikanan yang diolah justru harganya menjadi lebih murah dibandingkan dengan yang tidak diolah. ${ }^{41}$ Dengan karakteristik demikian di atas, maka komoditas perikanan yang lebih laku di pasar adalah ikan segar yang sebenarnya tidak dapat bertahan lama. Di sisi lain, pasar untuk ikan-ikan segar ini umumnya terletak di tempat yang jauh dari lokasi penangkapan ikan dan membutuhkan jangka waktu yang lama agar ikan tersebut sampai di lokasi atau pasar ikan. Sedangkan, ikan harus tetap segar untuk dapat laku di pasar.

Indonesia, berdasarkan data dari SEAFDEC merupakan produsen ikan tuna terbesar di Asia Tenggara, dengan komoditas andalan berupa frigate tuna, bullet tuna, skipjack tuna, longtail tuna, albacore tuna, southern bluefin tuna, yellowfin tuna dan bigeye tuna. ${ }^{42}$ Hingga saat ini, pasar tuna justru berada di bagian utara Indonesia, sehingga tunatuna yang ditangkap tersebut harus dibawa ke bagian utara Indonesia ${ }^{43}$ dan harus tetap segar. Namun, tuna sendiri merupakan komoditas perikanan yang memiliki jangka waktu hidup kurang dari empat puluh jam. ${ }^{44}$ Jika lebih dari empat puluh jam setelah ditangkap tuna-tuna tersebut tidak sampai di pasar, maka tuna-tuna tersebut akan mati, dan harga jualnya otomatis akan menurun. Sementara itu, untuk tuna-tuna yang diekspor dalam keadaan mati, ketidaktersediaan gudang pendingin (cold storage) yang baik dan memadai akan menyebabkan tuna-tuna tersebut tidak lagi segar ketika sampai

39 Wawancara lisan dengan Bono Budi Priambodo, Pengajar Matakuliah Hukum Lingkungan Fakultas Hukum Universitas Indonesia dan Penulis Buku Ikan untuk Nelayan, Depok, 22 Agustus 2014.

${ }^{40} \mathrm{Ibid}$.

41 Ibid. Lihat juga Dias Satria, “Antara Tuna Port Lincoln dan Tamperan," http://diassatria.lecture.ub.ac.id/2012/, diakses pada 28 Agustus 2014.

42 Southeast Asian Fisheries Development Center, op. cit., hal. 41, 43.

${ }^{43}$ Salah satu pasar lelang ikan internasional adalah di Jepang, yang memiliki permintaan tuna yang besar. Lihat Dias Satria, ibid.

${ }_{44}$ Bono Budi Priambodo memberikan contoh yaitu komoditas perikanan berupa salmon yang menjadi bahan utama untuk pembuatan sushi dan diternakkan di Norwegia Utara. Dalam waktu sekitar empat puluh jam, ikan-ikan salmon dari Norwegia Utara tersebut harus sampai di Jepang dalam keadaan segar untuk kemudian dijadikan bahan utama pembuatan sushi. Ikan salmon segar tersebutlah yang kemudian bernilai jual yang tinggi. 
di pasar. ${ }^{45}$ Oleh karena itu, maka agar tetap laku di pasar dan memiliki nilai jual yang tinggi, tuna-tuna tersebut harus sampai di pasar lebih cepat sebelum jangka waktu hidupnya habis dan tetap segar.

Letak pasar yang jauh, jangka waktu yang relatif singkat untuk menjaga kesegaran ikan, dan keterbatasan cold storage inilah yang kemudian menyebabkan praktik transhipment terus terjadi, terutama di daerah penghasil ikan di Indonesia Timur, di mana ikan-ikan yang ditangkap dialihmuatkan ke kapal lain yang memiliki fasilitas cold storage yang baik dan memadai untuk kemudian dibawa ke luar negeri untuk dijual. Dengan melakukan alih muatan di tengah laut tanpa mendaratkannya dulu di pelabuhan perikanan sekiranya dapat menghemat waktu, sehingga ikan-ikan tersebut akan tetap segar ketika sampai di pasar dan memiliki nilai jual yang tinggi.

Kemudian, dalam peraturan perundang-undangan yang berlaku di Indonesia, memang ditentukan bahwa ikan yang ditangkap haruslah didaratkan terlebih dahulu di pelabuhan perikanan untuk kemudian dicatatkan. ${ }^{46}$ Dengan tidak didaratkannya ikanikan tersebut maka akan menyebabkan biasnya pencatatan atau statistik perikanan, yang kemudian menimbulkan kerugian. Namun, pada kenyataannya terdapat perbedaan dengan apa yang diatur dalam peraturan perundang-undangan dengan keadaan di lapangan mengenai pencatatan ini.

Pertama, mengenai pelabuhan perikanan yang digunakan untuk mendaratkan ikan yang ditangkap. Pelabuhan perikanan merupakan unsur yang penting dalam hal pencatatan hasil tangkapan komoditas perikanan. Namun, pada kenyataannya banyak pelabuhan perikanan yang tidak dipakai karena letaknya yang tidak strategis maupun karena adanya pungutan liar, sehingga ikan-ikan akan dibawa ke pelelangan illegal ataupun dilakukan alih muatan sehingga mengacaukan statistik perikanan. ${ }^{47}$ Selain itu, keterbatasan fasilitas cold storage yang baik dan memadai pada di pelabuhan-pelabuhan, terutama di daerah Indonesia Timur, juga memicu dilakukannya alih muatan ini. Dengan begitu, maka jumlah ikan yang ditangkap di perairan Indonesia tidak tercatat sepenunya.

Kedua, dalam Pasal 44 ayat (3a) Peraturan Menteri Nomor 26/PERMENKP/2013 tentang Perubahan atas Peraturan Menteri Kelautan dan Perikanan Nomor PER.30/MEN/2012 tentang Usaha Perikanan Tangkap di Wilayah Pengelolaan Perikanan Negara Republik Indonesia, disebutkan bahwa penangkapan komoditas tuna segar dikecualikan untuk diolah dalam negeri. Ketentuan ini tentunya semakin memudahkan kegiatan transhipment, terlebih tuna merupakan komoditas perikanan yang menjadi unggulan Indonesia. Ketiga, menurut Bono Budi Priambodo, walaupun dalam UndangUndang tentang Perikanan ditentukan bahwa pengeluaran komoditas perikanan baru dapat dilakukan ketika telah ada pemenuhan konsumsi dalam negeri,48 pada

45 Sampai saat ini, Indonesia masih kekurangan cold storage, terutama di sentra-sentra perikanan, karena adanya keterbatasan listrik dan air bersih. Menurut Direktur Jenderal Perikanan Pemasaran dan Pengolahan Hasil Perikanan Kementerian Kelautan dan Perikanan, saat ini cold storage terbesar yang ada di Indonesia adalah di Jakarta. Kapasitasnya 75.000-80.000 ton. Namun, hal tersebut dinilai masih kurang, dan Indonesia membutuhkan cold storage yang memadai. Lihat Naomi Siagian, "Indonesia Kekurangan "Cold storage"," http://sinarharapan.co/news/read/140823141/indonesia-kekurangan-cold-storage- diakses pada 3 Oktober 2014. Selain itu, berdasarkan data dari Asosiasi Pengusaha Ikan Kaleng Indonesia (APIKI), Indonesia hanya memiliki $30 \%$ dari cold storage yang dimiliki oleh Thailand. Lihat Fauzul Muna, "INDUSTRIALISASI PERIKANAN: Cold storage $\mathrm{di}$ Tanah Hanya $30 \%$ dari Thailand," http://m.bisnis.com/industri/read/20140715/99/243295/industrialisasi-perikanan-cold-storage-di-tanah-airhanya-30-dari-thailand diakses pada 3 Oktober 2014.

46 Indonesia (3), Undang-Undang tentang Perubahan atas Undang-Undang Nomor 31 Tahun 2004 tentang Perikanan, UU No. 45 Tahun 2009, LN No. 154 Tahun 2009, TLN No. 5073, Pasal. 41 ayat (3).

47 Wawancara lisan dengan Bono Budi Priambodo, Pengajar Matakuliah Hukum Lingkungan Fakultas Hukum Universitas Indonesia dan Penulis Buku Ikan untuk Nelayan, Depok, 22 Agustus 2014.

48 Ibid., Pasal 25B ayat (2). 
kenyataannya masyarakat Indonesia tidak gemar makan ikan. Oleh karena itu, dibuatlah kebijakan bahwa ikan ditangkap untuk kemudian diekspor atau dijual ke luar negeri. ${ }^{49}$ Kebijakan ekspor ini dibarengi dengan kebutuhan untuk menjual ikan segar ke pasar ikan dunia inilah yang kemudian yang menjadi salah satu faktor yang dapat memicu transhipment. Dengan begitu, maka dapat dilihat bahwa pada dasarnya dewasa ini transhipment telah menjadi suatu kebutuhan dan juga menjadi solusi bisnis.

\section{Kesimpulan}

Indonesia memliki potensi yang sangat besar dalam hal industri perikanan, di mana berdasarkan data dari SEAFDEC Indonesia menempati peringkat pertama dalam hal produksi perikanan di Asia Tenggara. Berbagai macam peraturan dan kebijakan dikeluarkan untuk lebih meningkatkan produksi perikanan Indonesia, tetapi ternyata kebijakan-kebijakan yang ada belum dapat mengatasi permasalahan transhipment, yaitu pemindahan ikan hasil tangkapan dari kapal penangkap ikan ke kapal pengangkut ikan yang diatur dalam Peraturan Menteri Kelautan dan Perikanan Nomor 30/PERMEN-KP/2012 yang kemudian diubah dengan Peraturan Menteri Kelautan dan Perikanan Nomor 26/PERMEN-KP/2013. Namun ternyata, revisi tersebut masih membuka celah adanya alih muatan di laut melalui Pasal 37 ayat (7) dan (8) serta Pasal 37A, 37B dan 37C, yang mengatur persyaratan usaha pengangkutan ikan dengan pola kemitraan.

Transhipment sangat berpengaruh terhadap Hak Bangsa Indonesia atas komoditas perikanan maupun dengan elemen-elemen pembangunan berkelanjutan. Praktik transhipment memperburuk illegal dan unreported fishing yang marak terjadi di Indonesia, dan menimbulkan kerugian dimana ikan yang seharusnya menjadi hak bangsa Indonesia, justru tidak dapat dinikmati oleh bangsa Indonesia, baik untuk dikonsumsi ataupun sebagai pemasukan negara, karena telah dialihmuatkan dan dibawa ke luar negeri. Dengan begitu, maka hak bangsa Indonesia dan pembangunan berkelanjutan bagi generasi sekarang dan generasi yang akan datang pun akan terancam.

Dalam praktiknya, transhipment justru menjadi suatu kebutuhan karena produk perikanan akan bernilai jual tinggi apabila dijual dalam keadaan segar, sedangkan pendaratan ikan terlebih dahulu di pelabuhan perikanan akan memakan waktu dan ikan menjadi tidak segar. Selain itu, kurangnya keterbatasan cold storage yang baik dan memadai di Indonesia juga memicu dilakukannya praktik transhipment yang umumnya dilaksanakan di perairan perbatasan. Selain itu, terdapat pula perbedaan keadaan dengan apa yang ditentukan oleh peraturan perundangundangan dengan praktiknya, yang juga dapat membuka celah transhipment.

\section{Rekomendasi}

Adapun rekomendasi yang dapat diberikan oleh Penulis, di antaranya:

a. Merevisi peraturan perundang-undangan mengenai perikanan tangkap atau penangkapan ikan yang berlaku, sehingga tidak terdapat lagi celah untuk dilakukannya transhipment;

b. Pembentukan pengaturan mengenai cara pengukuran atau pencatatan jumlah ikan yang ditangkap, sehingga statistik perikanan tidak akan menjadi bias;

49 Wawancara lisan dengan Bono Budi Priambodo, Pengajar Matakuliah Hukum Lingkungan Fakultas Hukum Universitas Indonesia dan Penulis Buku Ikan untuk Nelayan, Depok, 22 Agustus 2014. Berdasarkan data dari Kementerian Kelautan dan Perikanan, jumlah ekspor perikanan Indonesia pada tahun 2012 adalah sebesar USD 3,85 juta. Lihat Kementerian Kelautan dan Perikanan, "Nilai Ekspor Hasil Perikanan," http://statistik.kkp.go.id/index.php/dashboard/c/5/?iframe=true\&width $=100 \% \&$ height $=95 \%$ diakses pada 27 Agustus 2014. 
c. Pengembangan kapasitas sumberdaya manusia dan kelembagaan dan penguatan sistem dan koordinasi antarpihak di tingkat lokal, nasional maupun internasional; serta melakukan pemantauan, pengendalian dan pengawasan terhadap kegiatan penangkapan ikan di perairan Indonesia, khususnya di daerah perbatasan;

d. Pengembangan kerjasama internasional, khususnya dalam hal hubungan bilateral, untuk meningkatkan promosi dan pemanfaatan sumberdaya ikan Indonesia, serta menjalin kerja sama statistik perikanan dengan negara lain untuk ikan-ikan yang ditangkap di Indonesia, baik secara bilateral maupun multilateral. Dengan begitu, maka ikan yang ditangkap maupun yang dialihmuatkan dapat didata dengan benar; dan

e. Pelestarian sumberdaya ikan dan penanggulangan transhipment dalam rangka menjalankan pembangunan berkelanjutan bagi bangsa Indonesia. 


\section{Daftar Pustaka}

Indonesia. Undang-Undang tentang Peraturan Dasar Pokok-Pokok Agraria. UU No. 5 Tahun 1960. LN No. 104 Tahun 1960. TLN Nomor 2043.

. Undang-Undang tentang Perikanan. UU No. 31 Tahun 2004. LN No. 118 Tahun 2004. TLN No. 4433.

Undang-Undang tentang Perubahan atas Undang-Undang Nomor 31 Tahun 2004 tentang Perikanan. UU No. 45 Tahun 2009. LN No. 154 Tahun 2009. TLN No. 5073.

Kementerian Kelautan dan Perikanan. Peraturan Menteri Kelautan dan Perikanan tentang Usaha Perikanan Tangkap di Wilayah Pengelolaan Perikanan Negara Republik Indonesia. Permen KKP Nomor 30/PERMEN-KP/2012.

Peraturan Menteri Kelautan dan Perikanan tentang Perubahan atas Peraturan Menteri Kelautan dan Perikanan Nomor 30/PERMEN-KP/2012 tentang Usaha Perikanan Tangkap di Wilayah Pengelolaan Perikanan Negara Republik Indonesia. Permen KKP Nomor 26/PERMEN-KP/2013.

Keputusan Menteri Kelautan dan Perikanan tentang Rencana Aksi Nasional Pencegahan dan Penanggulangan Illegal, Unreported, and Unregulated Fishing. Kepmen KKP Nomor 50 Tahun 2012.

Ariadno, Melda Kamil. 2007. Hukum Internasional Hukum yang Hidup. Jakarta: Diadit Media.

Beder, Sharon. 2006. Environmental Principles and Policies: An Interdiciplinary Introduction. Oxford: Earthscan.

Brenton, T. 1994. The Greening of Machiavelli: the Evolution of International Environmental Politics. London: Earthscan.

Harsono, Boedi. 2013. Hukum Agraria Indonesia Sejarah Pembentukan Undang-Undang Pokok Agraria, Isi dan Pelaksanaannya. Jakarta: Universitas Trisakti.

Priambodo, Bono Budi. 2013. Ikan untuk Nelayan. Depok: Badan Penerbit Fakultas Hukum Universitas Indonesia.

Sands, Philippe. 1995. Principles of International Environmental Law: Vol. 1, Frameworks, Standards, and Implementation. Manchester: Manchester University Press.

Southeast Asian Fisheries Development Center. 2013. Fishery Statistikal Bulletin of Southeast Asia 2011. Bangkok: Southeast Asian Fisheries Development Center.

Winter, Gerd (Ed). 2009. Toward Sustainable Fisheries Law. A Comparative Analysis. Switzerland: IUCN.

Muhamad, Simela Victor. "Kejahatan Transnasional Illegal fishing di Perairan Indonesia dan Upaya Penanganannya Secara Regional di Asia Tenggara." Dalam Laporan Hasil Penelitian Pusat Pengkajian, Pengolahan Data, dan Informasi (P3DI) Sekretariat Jenderal Dewan Perwakilan Rakyat Republik Indonesia tentang Masalah-Masalah Hubungan Internasional pada Tahun 2011.

Wibisana, Andri G. "Pembangunan Berkelanjutan: Status Hukum dan Pemaknaannya." Jurnal Hukum dan Pembangunan. Volume 43. Nomor 1. Januari 2013. Depok: Badan Penerbit Fakultas Hukum Universitas Indonesia.

Administrator. "KNTI Tolak Izin Transhipment Kapal 1000 GT." http:/ / www.republika.co.id/berita/ekonomi/bisnis/13/03/13/mjla4u-knti-tolak-izintranshipment-kapal-1000-gt diakses pada 22 Agustus 2014.

Hida, Ramdhania El. "Konsumsi Ikan Orang Indonesia Hanya Seperlima Jepang." http:/ / finance.detik.com/read/2011/08/24/165017/1710441/4/konsumsi-ikan-orangindonesia-hanya-seperlima-jepang diakses pada 27 Agustus 2014. 
Kementerian Kelautan dan Perikanan. "Nilai Ekspor Hasil Perikanan." http:/ / statistik.kkp.go.id/index.php/dashboard/c/5/?iframe=true\&width $=100 \%$ \&heigh $\underline{\mathrm{t}=95 \%}$ diakses pada 27 Agustus 2014 .

"Angka Konsumsi Ikan." http:/ / statistik.kkp.go.id/index.php/dashboard/c/4/?iframe=true\&width=100\%\&heigh $\mathrm{t}=95 \%$ diakses pada 27 Agustus 2014 .

"Volume Produksi Perikanan." http:/ / statistik.kkp.go.id/index.php/dashboard/c/3/?iframe=true\&width=100\%\&heigh $\underline{\mathrm{t}=95 \%}$ diakses pada 27 Agustus 2014 .

Mukhtar. "Kerugian Negara di Perairan Laut Aru dan Laut Arafura." http://www.kkp.go.id/index.php/arsip/c/10347/Kerugian-Negara-di-Perairan-LautAru-dan-Laut-Arafura/?category_id=91 diakses pada 22 Agustus 2014.

Muna, Fauzul. "INDUSTRIALISASI PERIKANAN: Cold storage di Tanah Air Hanya 30\% dari Thailand," $\quad$ http://m.bisnis.com/industri/read/20140715/99/243295/industrialisasiperikanan-cold-storage-di-tanah-air-hanya-30-dari-thailand diakses pada 3 Oktober 2014.

Prasetyo, Sulung. "Pencurian Ikan Meningkat Drastis." http://www.kiara.or.id/pencurian-ikanmeningkat-drastis/ diakses pada 22 Agustus 2014.

Satria, Dias. "Antara Tuna Port Lincoln dan Tamperan." http:/ / www.diassatria.lecture.ub.ac.id/2012/ diakses pada 28 Agustus 2014.

Siagian, Naomi. "Indonesia Kekurangan "Cold storage"." http:/ / sinarharapan.co/news/read/140823141/indonesia-kekurangan-cold-storagediakses pada 3 Oktober 2014.

Simanjuntak, Ranap. "Cold Storage: Hangatnya Proyek Pendingin." http://m.sindoweeklymagz.com/artikel/11/i/17-23-mei-2012/business/22/hangatnya-proyek-pendinginn diakses pada 3 Oktober 2014.

Subekti, Sabar. "Pencurian Ikan Masih Marak di Lautan Indonesia." http://www.satuharapan.com/read-detail/read/pencurian-ikan-masih-marak-dilautan-indonesia diakses pada 3 Oktober 2014.

Wawancara lisan dengan Bono Budi Priambodo. Pengajar Matakuliah Hukum Lingkungan Fakultas Hukum Universitas Indonesia dan Penulis Buku Ikan untuk Nelayan. Depok, 22 Agustus 2014. 